\title{
A Case of Failure to Thrive- Investigation Beyond a Positive Sweat Test
}

\section{Büyüme Gelişme Geriliği Olan Vaka- Pozitif Ter Testinin Ötesinde Bir Araştırma}

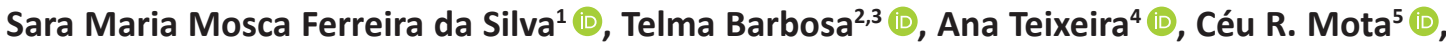 \\ Teresa Costa $^{4}\left(\mathbb{D}\right.$, Liane Correia-Costa ${ }^{4}[\mathbb{C}$
}

\author{
${ }^{1}$ Centro Hospitalar Universitário do Porto, Centro Materno-Infantil do Norte, Porto, Portugal \\ ${ }^{2}$ Centro Hospitalar Universitário do Porto, Pediatric Department, Centro Materno-Infantil do Norte, Porto, Portugal \\ ${ }^{3}$ Centro Hospitalar Universitário do Porto, Coordinator of the Reference Center of Cystic Fibrosis, Porto, Portugal \\ ${ }^{4}$ Centro Hospitalar Universitário do Porto, Centro Materno-Infantil do Norte, Pediatric Department, Pediatric Nephrology Unit, Porto, Portugal \\ ${ }^{5}$ Centro Hospitalar e Universitário do Porto, Centro Materno-Infantil do Norte, Pediatric Intensive Care and Neonatology Department, Porto, Portugal
}

ORCID ID: S.M.M.F.D.S. 0000-0002-5474-7236; T.B. 000-0003-4641-2898; A.T. 0000-0001-5211-2467; C.R.M. 0000-0001-5280-0788; T.C. 0000-0002-6478-4241; L.C.C. $0000-0002-8216-090 \mathrm{X}$

Citation/Atf: Mosca Ferreira da Silva SM, Barbosa T, Teixeira A, Mota CR, Costa T, Correia-Costa L. A Case of failure to thrive- investigation beyond a positive sweat test. Çocuk Dergisi - Journal of Child 2021;21(1):86-88. https://doi.org/10.26650/jchild.2021.766768

ABSTRACT

Failure to thrive represents a difficult entity to define and can be associated with several diseases. Therefore, combining all the data (family history, perinatal and infancy information) with the physical examination and laboratory findings is a fundamental step to reach the correct diagnosis. A comprehensive and structured diagnostic approach is required in order to select between cystic fibrosis, innate errors of the metabolism or malabsorption syndromes as possible causes. The sweat test is the goldstandard method to diagnose cystic fibrosis although it is widely recognized that there are some inherent limitations to the test. For that reason, it is important to discuss unexpected results and to reassess, when possible, the exams previously performed, which can be crucial to make the diagnosis. Here, the authors report a patient with minor dysmorphic features associated with failure to thrive and a positive result for the sweat test and its following investigation to achieve the definite diagnosis of Bartter syndrome.

Keywords: Failure to thrive, Bartter syndrome, polyuria, nephrocalcinosis öz

Büyüme gelişme geriliği tanımlanması zor bir kavramdır ve bir çok hastalıkla ilişkili olabilir. Bu nedenle, tüm verilerin (aile öyküsü, perinatal ve süt çocukluğuna ait bilgiler) fizik muayene ve laboratuvar bulguları ile birleştirilmesi doğru tanıya ulaşmak için temel basamaktır. Kistik fibroz, doğumsal metabolik hastalıklar veya malabsorpsiyon sendromları gibi olası nedenler arasında doğru tanıya ulaşmak için kapsamlı ve yapılandırıımış bir tanı yaklaşımı gereklidir. Kistik fibroz tanısında ter testi altın standart tanı yöntemdir fakat testin bazı sınırlamaları olduğu yaygın olarak kabul görmektedir. Bu nedenle, beklenmedik sonuçları mümkün olduğunda tekrarlamak ve daha önce yapılan muayeneleri yeniden değerlendirmek tanı için önemlidir. Yazarlar burada büyüme gelişme geriliği ile ilişkili minor dismorfik bulguları olan ve ter testi pozitif olan bir hastada Bartter sendromu kesin tanısına ulaşmak için yapılan sonraki incelemeler bildirilmiştir.

Anahtar Kelimeler: Büyüme gelişme geriliği, Bartter sendromu, poliüri, nefrokalsinozis

physical examination and laboratory assessment, is required in order to establish a diagnosis. After conducting a basic initial study which regularly includes a complete blood count, a blood gas analysis, serum electrolytes, lactate and iron status evaluation, thyroid function, an urinalysis and urine culture, when a diagnosis is not reached, the request for further exams such as sweat test is usually guided by the particularities and initial findings in each case.

Corresponding Author/Sorumlu Yazar: Sara Maria Mosca Ferreira da Silva E-mail: sara.mosca.silva@gmail.com

Submitted/Başvuru: 07.11.2020 • Revision Requested/Revizyon Talebi: 08.03.2021 • Last Revision Received/Son Revizyon: 14.03.2021 •

Accepted/Kabul: 28.03.2021 
The sweat test is the gold-standard method to diagnose cystic fibrosis although it is widely recognized that there are some inherent limitations to the test; it is cumbersome to perform, technically challenging and vulnerable to errors such as false positive results even when the technique is properly executed (5). Thus, when a positive result (sweat chloride $>60 \mathrm{mmol} / \mathrm{L}$ ) is obtained, it is fundamental to repeat the test and to review patients' clinical history comprehensively.

\section{CASE PRESENTATION}

A 15-month-old boy was referred to the Pediatric Department of a tertiary care hospital due to failure to thrive. The family history was unremarkable with no parental consanguinity. He was born at 36 weeks of gestation, with 2880 grams and 50 centimeters $\left(50-90^{\text {th }}\right.$ percentile for weight and $90^{\text {th }}$ percentile for length of the Fenton curves), an Apgar score of 8/9, at $1^{\text {st }}$ and $5^{\text {th }}$ minute, respectively. Polyhydramnios had been known to be present since the $32^{\text {nd }}$ week of gestation. Information on the $1^{\text {st }}$ stool passed was not available. As a newborn, several minor dysmorphic features (camptodactyly, large eyes, prominent forehead, cavus feet) and sensorineural hearing loss were identified. Cochlear implants were surgically placed at the age of 2 months. Breastfeeding and bottle-feeding were combined until the age of 6 months until solids were gradually introduced (infant cereal, fruits, vegetable puree with meat and fish). Up until 7 months, a weight gain of around $135 \mathrm{~g}$ per week was recorded, but between the $7^{\text {th }}$ and the $13^{\text {th }}$ months, severe weight gain deceleration was noted, crossing from between $15^{\text {th }}-50^{\text {th }}$ percentile to the $3^{\text {rd }}$ percentile and with a weight gain of around $20 \mathrm{~g}$ per week. Considering growth evolution, from birth until the age of 15 months, he presented consistent growth deceleration, crossing from $50^{\text {th }}-90^{\text {th }}$ percentile to $3^{\text {rd }}$ - $15^{\text {th }}$ percentile (length $75 \mathrm{~cm}$ at 15 months). Psychomotor development was normal.

No respiratory symptoms, diarrhea, steatorrhea or vomiting had been reported in the previous months.

The initial laboratory evaluation included stool analysis with parasitology, celiac disease and organic acids screening tests and thyroid function determination, which showed no relevant alterations. Nonetheless, the sweat test was positive (chloride $88 \mathrm{mmol} / \mathrm{L}$ ). At this point, he was referred to the cystic fibrosis outpatient clinic, and the sweat test was repeated twice (chloride 41 and $8 \mathrm{mmol} / \mathrm{L}, 1$ and 3 months after the $1^{\text {st }}$ test, respectively). After ruling out cystic fibrosis as a probable diagnosis, the parents reported, after being asked several times, that over the last 6 months his son presented excessive fluid intake, including night awakening because of thirst, associated with polyuria. He was referred to the Pediatric Nephrology outpatient clinic where polyuria and polydipsia were confirmed (diuresis $8 \mathrm{~mL} / \mathrm{kg} /$ day and fluid intake $2.5 \mathrm{~L}$ water/day). Blood gas analysis showed metabolic alkalosis $(\mathrm{pH}$ 7.5 , bicarbonate $28.8 \mathrm{mmol} / \mathrm{L}$ ) with hypokalemia ( $2.8 \mathrm{mmol} / \mathrm{L})$. Renal ultrasound revealed nephrocalcinosis. The diagnosis of Bartter syndrome was considered and shortly after confirmed by the genetic sensorineural hearing loss workup that had already been performed. A homozygous pathogenic variant c.139G>A (Gly47Arg), responsible for Bartter syndrome type IVa phenotypes, was identified. Indomethacin and potassium supplements were initiated, with optimal response. Weight and height progressed favorably. At 3-year-old, both weight and height increased and reached the $15^{\text {th }}$ and $15^{\text {th }}-50^{\text {th }}$ percentile, respectively. The psychomotor development also showed a good evolution, with language development being slightly delayed but with remarkable progresses with speech and occupational therapy. The family signed an informed consent for this case report.

\section{DISCUSSION}

The present clinical case reinforces the importance of considering renal tubular disorders as a differential diagnosis when assessing a child with FTT, as they represent a considerable proportion of kidney diseases in the pediatric age, presenting as FTT (5-7). In this case, despite the prenatal diagnosis of polyhydramnios, the presence of late prematurity associated with a number of minor dysmorphic features and hearing loss, the diagnosis of Bartter disease was slightly delayed while other basic initial investigations were performed. Nonetheless, as soon as the parents described excessive fluid intake and diuresis, the diagnosis of a renal tubular disorder was immediately pursued and confirmed. However, it is important to point out that the presence of FTT and neurosensorial hearing loss must always warrant a prompt investigation of a kidney disease.

The sweat test is known to be affected by the presence of some conditions that are sometimes responsible for false positive results, namely celiac disease, malnutrition, adrenal insufficiency, nephrogenic diabetes insipidus and renal tubular disorders (5-8). In the presence of a positive sweat test, the determination of fecal elastase may be indicated, especially if steatorrhea is present, nevertheless the repetition of the sweat test may be done in the first place (8).

Bartter syndrome is a renal tubular disorder with an autosomal recessive inheritance pattern, which results in an impairment of salt reabsorption in the loop of Henle. Some of the most frequent clinical manifestations include polyhydramnios, premature delivery, sensorineural hearing loss (specific of Bartter syndrome type IV) and distinctive facial characteristics (triangular face, prominent forehead, large eyes, protruding ears, and a drooping mouth). Further findings include FTT, nephrocalcinosis (less commonly in type IV), polyuria and polydipsia (urine concentration impairment), with consequent hypochloremia and hypokalemic metabolic alkalosis, which may explain the false positive results in the sweat test (7-9). Genetic testing is essential for the identification of the specific gene mutation and Bartter syndrome type as well as to allow adequate family genetic counseling. An early diagnosis allowing prompt and adequate management is fundamental to ensure correct psychomotor development, with a good catch-up growth, metabolic and electrolyte stability and prevention of progressive kidney dysfunction $(7,10,11)$. A close long-term 
follow-up is always needed in patients with this type of renal tubular disorders, but information on long-term prognosis, risk for complications and treatment alternatives is still scarce.

\section{CONCLUSION}

In conclusion, with this case, the authors would like to highlight the importance of an integrated multidisciplinary approach when assessing children with FTT, especially in presence of clinical clues that can help to narrow the diagnostic hypothesis. In this setting, the consideration of a specific and rare diagnosis should be prompt in order to allow the adequate management.

Informed Consent: Written consent was obtained from the participants.

Peer Review: Externally peer-reviewed.

Author Contributions: Conception/Design of Study- S.M.M.F.D.S., T.B., L.C.C.; Data Acquisition- S.M.M.F.D.S., A.T., C.R.M., L.C.C.; Data Analysis/ Interpretation- S.M.M.F.D.S., T.B., A.T., T.C., L.C.C.; Drafting ManuscriptS.M.M.F.D.S., A.T., L.C.C..; Critical Revision of Manuscript- T.B., A.T., C.R.M., T.C., L.C.C.; Final Approval and Accountability- S.M.M.F.D.S., T.B., A.T., C.R.M., T.C., L.C.C.

Conflict of Interest: Authors declared no conflict of interest.

Financial Disclosure: Authors declared no financial support.

Bilgilendirilmiş Onam: Katılımcılardan bilgilendirilmiş onam alınmıştır

Hakem Değerlendirmesi: Dış bağımsız.

Yazar Katkıları: Çalışma Konsepti/Tasarım- S.M.M.F.D.S., T.B., L.C.C.; Veri Toplama- S.M.M.F.D.S., A.T., C.R.M., L.C.C.; Veri Analizi/YorumlamaS.M.M.F.D.S., T.B., A.T., T.C., L.C.C.; Yazı Taslağı- S.M.M.F.D.S., A.T., L.C.C..; İçeriğin Eleştirel İncelemesi- T.B., A.T., C.R.M., T.C., L.C.C.; Son Onay ve Sorumluluk- S.M.M.F.D.S., T.B., A.T., C.R.M., T.C., L.C.C.
Çıkar Çatışması: Yazarlar çıkar çatışması beyan etmemişlerdir.

Finansal Destek: Yazarlar finansal destek beyan etmemişlerdir.

\section{REFERENCES}

1. Jaffe AC. Failure to thrive: current clinical concepts. Pediatr Rev $2011 ; 32(3): 100-8$.

2. Lazzara A, Daymont C, Ladda R, Lull J, Ficicioglu C, Cohen JL, et al. Failure to thrive: an expanded differential diagnosis. J Pediatr Genet 2019; 8(1):027-32.

3. Marcdante KJ, Nelson Essentials of Pediatrics, 8th ed, Vol. 1, Elsevier, 2018.p.244-252.

4. Larson-Nath C, Biank VF. Clinical review of failure to thrive in pediatric patients. Pediatr Ann 2016; 45(2):e46-9.

5. Maia C, Garrido A, Carvalho I, Pinto H, Vaz L, Ferreira G. PseudoBartter syndrome as an initial presentation of cystic fibrosis. Port J Nephrol Hypertens 2014; 28(4):348-51.

6. Kiran Bv, Barman $\mathrm{H}$, Iyengar A. Clinical profile and outcome of renal tubular disorders in children: a single center experience. Indian J Nephrol 2014; 24(6):362.

7. Edmondson C, Grime C, Prasad A, Cowlard J, Nwokoro C, Ruiz G, et al. Cystic fibrosis newborn screening: outcome of infants with normal sweat tests. Arch Dis Child 2018; 103(8):753-756.

8. Cunha TS, Heilberg IP. Bartter syndrome: Causes, diagnosis, and treatment. Int J Nephrol Renovasc Dis 2018; 11:291-301.

9. Gajendragadkar A, Bhamkar R. Antenatal Bartter's syndrome with sensorineural deafness. Indian J Nephrol 2009; 19(1): 23.

10. Calò LA, Ravarotto V. Bartter and Gitelman Syndromes. Encyclopedia of Endocrine Diseases, 2nd ed, Vol. 3, Elsevier, 2019; 3: 713-21. https://doi.org/10.1016/B978-0-12-801238-3.65335-7.

11. Colussi G. Bartter syndrome. Orphanet Encycl 2005, Available from: URL: http://www.orpha.net/data/patho/GB/uk-Bartter.pdf. Accessed 28 November 2019. 